\title{
USE OF FINE GROUND DUNE SAND AS A SUPPLEMENTARY CEMENTING MATERIAL
}

\author{
Abdulrahman ALHOZAIMYa, Omer Abdalla ALAWAD ${ }^{\mathrm{b}}$, Mohd Saleh JAAFAR ${ }^{\mathrm{b}}$, \\ Abdulaziz AL-NEGHEIMISH ${ }^{\mathrm{a}}$, Jamaloddin NOORZAEI ${ }^{\mathrm{b}}$ \\ ${ }^{a}$ Civil Engineering Department and Center of Excellence for Concrete Research and Testing, \\ King Saud University, Riyadh, Saudi Arabia \\ ${ }^{b}$ Civil Engineering Department, Faculty of Engineering, Universiti Putra Malaysia, \\ 43400 UPM-Serdang, Malaysia
}

Received 04 Apr 2011; accepted 26 Oct 2011

\begin{abstract}
The process of Portland cement production is associated with high consumption of energy and resources. Therefore, there is a need to replace the Portland cement with environmental friendly materials. This study was conducted to determine the feasibility of using ground dune sand as cement replacement materials under different curing conditions. Portland cement was replaced by ground dune sand at five levels of replacement ( $0-40 \%$ by weight). The compressive strength of mortar under standard and autoclave curing conditions and the influence of different autoclave temperatures and durations were investigated. The microstructure of selected mixtures was analyzed by XRD and SEM. Results showed that the compressive strength under the standard curing decreased as the level of replacement increased. However, under autoclave curing compressive strength increased as the content of ground dune sand increased. XRD and SEM revealed the absence of calcium hydroxide and the formation of secondary calcium silicate hydrate. The improvement of compressive strength and the absence of calcium hydroxide under autoclave curing indicated that the pozzolanic reaction between silica of dune sand and calcium hydroxide occurred.
\end{abstract}

Keywords: dune sand, autoclave curing, pozzolanic materials, compressive strength, XRD, SEM.

Reference to this paper should be made as follows: Alhozaimy, A.; Alawad, O. A.; Jaafar, M. S.; AL-Negheimish, A.; Noorzaei, J. 2014. Use of fine ground dune sand as a supplementary cementing material, Journal of Civil Engineering and Management 20(1): 32-37. http://dx.doi.org/10.3846/13923730.2013.768541

\section{Introduction}

Manufacturing of Portland cement consumes a considerable amount of energy and natural resources. The production of one ton of Portland cement requires about 4 GJ of energy and about 1.7 tons of raw materials (limestone and shale) which leads to environmental destruction and pollution problem (Malhotra 2000; Sabir et al. 2001; Worrell et al. 2001). There is a clear need to find materials which can be used as cement replacement material.

Pozzolan materials such as ground granulated blast furnace slag (GGBS), fly ash (FA), silica fume (SF) and natural pozzolan have been used successfully as substituting materials for Portland cement. These materials consist of high silica content in non-crystalline form (Sabir et al. 2001). Published data demonstrated that the use of pozzolan materials in concrete would result in ecological, technical and economic benefits (Hassan et al. 2000; Khatri et al. 1995; Malhotra et al. 2000; Malhotra 1993; Mehta 2004; Yazic1 et al. 2008).

However, the use of pozzolanic materials lead to various disadvantages including: increased setting time; slow rate of strength development; prolonged period of curing; increased water demand; increased superplasticizer dosage; and placing problem (Ghrici et al. 2006; Thomas et al. 1999). Furthermore, some pozzolana materials are becoming expensive and unavailable in market (Erdem, Kırca 2008; Cassagnabère et al. 2009). Due to above mentioned reasons, researchers are seeking for cheap and easily available cement replacement materials.

Thermal treatment method is used to improve the reactivity of some natural and by-product pozzolans. Metakaolin and rice husk ash were obtained by clacination of kaolin clay and burning of rice husk under controlled temperature, respectively (Sabir et al. 2001; Chandrasekhar et al. 2003). High strength concrete could be achieved by incorporating ground quartz sand and fine stone dust as a partial cement replacement in an autoclave curing system (Jaafar et al. 2002; Yang et al. 2000).

A number of studies reported that the use of crystalline silica performed better than amorphous silica under autoclave curing (Luke 2004; Jupe et al. 2008). Autoclaving amorphous silica such as silica fume, fly

Corresponding author: Jamaloddin Noorzaei

E-mail: jamal@eng.upm.edu.my 
ash and natural zeolite were reported to display lesser strength than autoclaving crystalline silica (Luke 2004). Oyefesobi and Roy (1976) found that glassy silica was more reactive than the quartz silica at temperature below $100{ }^{\circ} \mathrm{C}$, however, at temperature above $100{ }^{\circ} \mathrm{C}$ quartz silica showed better performance.

Dune sand is an abundant natural material, with high content of quartz silica (Cisse, Laquerbe 2000; Laquerbe et al. 1995). Due to fine particles (100\% passing $600 \mu \mathrm{m})$ and uniform shape, dune sand does not meet the standard limit of the fine aggregate gradation recommended by ASTM C 33 and BS882 (Al-Harthy et al. 2007). Therefore, it has been used as partial replacement sand for fine aggregate and backfilling materials only (Al-Sanad et al. 1993).

A very limited work has been carried out to study the possibility of using dune sand as cement replacement materials (Guettala, Mezghiche 2011). However, no attempt has been made so far to utilize the ground dune sand as supplementary cementitions materials in mortar or concrete.

The objective of this study was to investigate the optimum level of cement replacement using ground dune sand; optimum curing cycle and provide microstructure analysis of the hydration products. The outcome of study is expected to encourage the use of dune sand as a cement replacement material in concrete industry.

\section{Material and method}

Dune sand (DS) used in this work was obtained from Saudi Arabia. The DS was mechanically ground to approximately cement fineness (95\% passing a $45 \mu \mathrm{m}$ opening size). The SEM image and XRD analysis of ground DS is shown in Figures 1 and 2, respectively. The chemical composition of DS is presented in Table 1. Ordinary Portland cement (OPC) which complies with ASTM C 150 was used in this study. The chemical composition and physical properties of OPC are given in Tables 1 and 2, respectively. Standard sand (Minining sand) with maximum particle size of $2.36 \mathrm{~mm}$ was used as fine aggregate in mortar mixtures. The specific gravity and fineness modulus of the standard sand was 2.5 and 2.49, respectively.

Standard consistency and the setting time of cement and dune sand-cement pastes were determined by Vicat probe and Vicat needle apparatus. Control (CTRL) mixture contained only Portland cement as binder material. In the other mixtures, Portland cement was partially replaced with ground DS. The levels of cement replacement by DS were 10, 20, 30 and $40 \%$ (by weight) and the mixture were labelled as DS10, DS20, DS30 and DS40

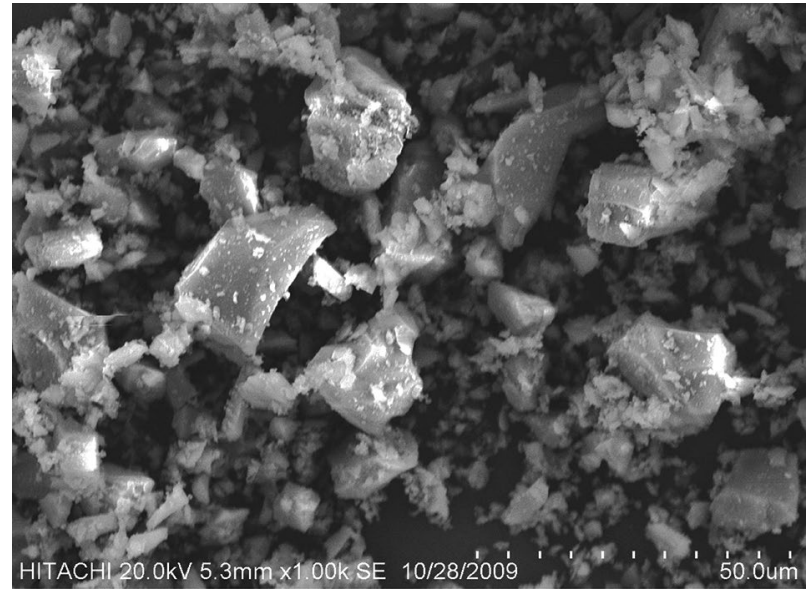

Fig. 1. SEM image of ground dune sand

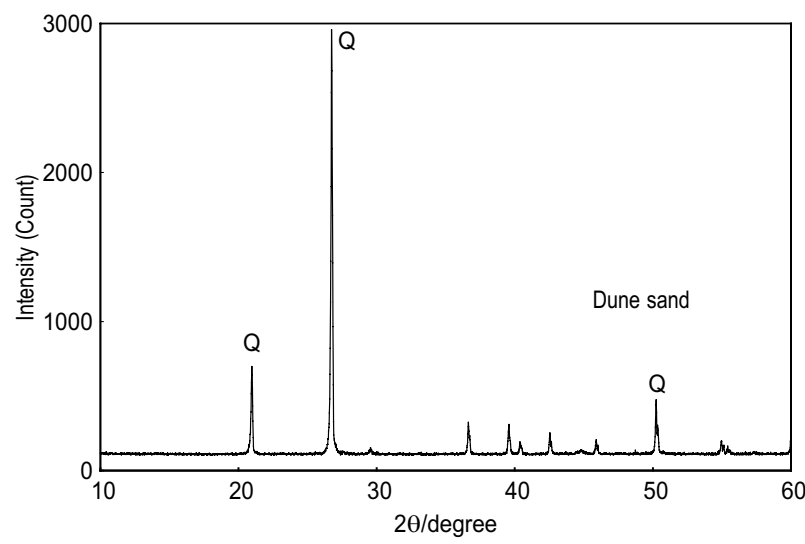

Fig. 2. XRD analysis of Dune sand

respectively (Table 3 ). The fine aggregate to binder (cement and DS) and water to binder ratios used for all mixtures were $3: 1$ and $0.5: 1$, respectively. The mixtures were prepared by the procedure specified in ASTM C 305. Mortar specimens were cast into cube of $50 \mathrm{~mm}$ and compacted on a vibration table for about $15 \mathrm{sec}$.

All specimens were covered with plastic sheets and stored in air at $23 \pm 5^{\circ} \mathrm{C}$ for 24 hours. The specimens were then demolded and cured under one of two curing conditions: standard curing (immersion in water at $23 \pm 2{ }^{\circ} \mathrm{C}$ ) or autoclave curing. Three specimens were cured under standard conditions for 28 days. The remaining specimens subjected to autoclave curing were first held under standard curing conditions for 16 hours to develop initial strength and then placed in the autoclave chamber.

The autoclave curing was used for two purposes; first, to investigate the optimum level of cement replacement using DS under autoclave curing and secondly to investigate the optimum autoclave curing condition. To

Table 1. Chemical analysis (\%) of the materials used

\begin{tabular}{lcccccccccccc}
\hline & $\mathrm{SiO}_{2}$ & $\mathrm{Fe}_{2} \mathrm{O}_{3}$ & $\mathrm{Al}_{2} \mathrm{O}_{3}$ & $\mathrm{CaO}$ & $\mathrm{MgO}$ & $\mathrm{SO}_{3}$ & $\mathrm{MnO}$ & $\mathrm{TiO}_{2}$ & $\mathrm{~K}_{2} \mathrm{O}$ & $\mathrm{Na}_{2} \mathrm{O}$ & $\mathrm{ZrO}_{2}$ & $\mathrm{IOI}$ \\
\hline OPC & 22.62 & 4.69 & 7.11 & 57.96 & 2.16 & 2.99 & - & - & 0.98 & 0.17 & - & 1.8 \\
\hline Dune sand & 88.78 & 0.52 & - & 3.66 & - & - & 0.03 & 0.16 & 0.64 & - & 0.03 & - \\
\hline
\end{tabular}


Table 2. Physical properties of Portland cement paste and mortar

\begin{tabular}{cc}
\hline \multicolumn{1}{c}{ Property } & Result \\
\hline Normal consistency (\%) & 33 \\
\hline Setting time (min) & 110 \\
\hline (a) Initial & 180 \\
\hline (b) Final & \\
\hline Compressive strength (MPa) & 21 \\
\hline (a) 3 days & 33 \\
\hline (b) 7 days & 46.6
\end{tabular}

Table 3. Mixture proportions of mortar specimens

\begin{tabular}{lccccc}
\hline \multicolumn{1}{c}{ Material } & \multicolumn{5}{c}{ Mortar mixtures } \\
\hline & CTRL & DS10 & DS20 & DS30 & DS40 \\
\hline Cement & 500 & 450 & 400 & 350 & 300 \\
\hline DS & - & 50 & 100 & 150 & 200 \\
\hline Fine aggregate & 1500 & 1500 & 1500 & 1500 & 1500 \\
\hline w/(c + DS $)$ & 0.5 & 0.5 & 0.5 & 0.5 & 0.5 \\
\hline
\end{tabular}

achieve the first objective, autoclave temperature was increased from room temperature to $182^{\circ} \mathrm{C}$ in 1 hour. Correspondingly, the pressure was increased from atmospherical pressure to $1.0 \mathrm{MPa}$ and remained constant for 5 hours. After 5 hours the autoclave heater was turned off to cool and the room temperature was attained in 45 minutes. To investigate the optimum curing conditions, different temperatures and periods of curing were used. Temperatures of $182,200,210$ and $220^{\circ} \mathrm{C}$ were applied, whereas the two periods of curing used were 5 and 8 hours.

After completion of their curing periods, specimens were tested under a uniaxial compressive test machine. The rate of loading of the testing machine was $0.75 \mathrm{KN} /$ sec. The compressive strength is reported as the average of three specimens. The mineralogical composition of the hydration products were determined by X-ray diffraction, using a Shimadzu XRD-6000 diffractometer with a scanning rate of $2^{\circ} / \mathrm{min}$ from $10^{\circ}$ to $60^{\circ}(2 \theta)$. Scanning electron microscopy (SEM) was used to investigate the morphology of the hydration products. The S-3400N machine was used for that purpose.

\section{Result and discussion}

\subsection{Normal consistency and setting time of dune sand- cement mixture}

The normal consistency and the setting time of dune sand-cement pastes are presented in Table 4. Water demand for the standard consistency was not affected by the replacement of cement by DS (Table 4).

This could be explained by the surface roughness and the angular shape of DS particles as shown in SEM
Table 4. Normal consistency and setting time of dune sand-cement pastes

\begin{tabular}{cccc}
\hline \multirow{2}{*}{ Mixture ID } & $\begin{array}{c}\text { Normal } \\
\text { Consistency (\%) }\end{array}$ & \multicolumn{2}{c}{ Setting time (minutes) } \\
\cline { 3 - 4 } & 33 & Initial & Final \\
\hline CTRL & 33 & 110 & 180 \\
\hline DS10 & 32 & 110 & 180 \\
\hline DS20 & 32 & 120 & 185 \\
\hline DS30 & 32 & 120 & 185 \\
\hline DS40 & & & 185 \\
\hline
\end{tabular}

image (Fig. 1) (Garcés et al. 2008). The slight increase in the setting time for mixtures containing DS where the replacement is higher than $10 \%$ could be attributed to the less $\mathrm{C}_{3} \mathrm{~S}$ and $\mathrm{C}_{3} \mathrm{~A}$ content in the total blended mixture. Therefore, fewer products of $\mathrm{CSH}$ and ettringite were produced in the early stage of hydration, which leads to slow strength development and retards the setting time (Hewlett 2003).

\subsection{Compressive strength of mortar}

Figure 3 shows the results of compressive strength of mortars after standard and autoclave curing. The compressive strength of mortars cured under standard curing decreased with the increased level of cement replacement by ground DS. At 10, 20, 30 and 40\% replacement level the compressive strength was reduced by about 25,38 , 43 and $52 \%$, respectively, compared to the CRTL mixture. The reduction can be attributed to lesser cement content in the mixtures, increased water to cement ratio and DS acted as a filler materials. The results indicate there was no pozzolanic reaction for the DS under normal condition.

For the autoclave curing, all mixtures containing ground DS displayed compressive strength higher than CTRL mixture (Fig. 3). This can be attributed to the fact that under autoclave curing, quartz $\mathrm{SiO}_{2}$ in $\mathrm{DS}$ reacted with calcium hydroxide $(\mathrm{CH})$ generated from the hydration of cement to produce additional secondary cementitious matrix.

The maximum compressive strength was obtained at $30 \%$ level of OPC replacement by DS $(46 \mathrm{MPa})$. The $30 \%$ replacement of cement by ground DS lowered the $\mathrm{Ca} / \mathrm{Si}$ ratio to be around unity which is associated with

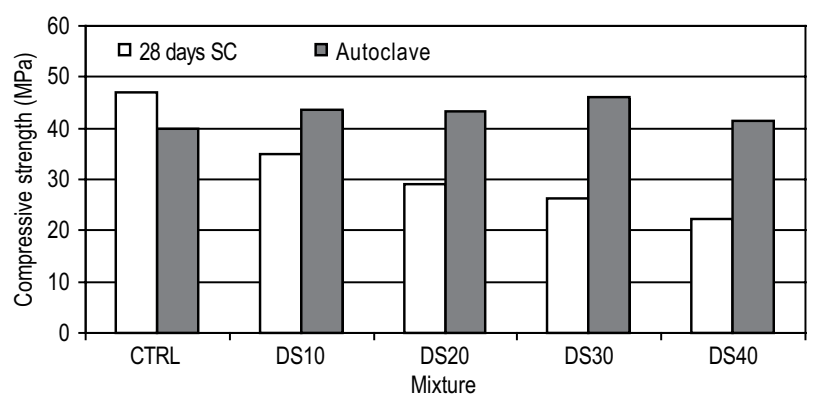

Fig. 3. Compressive strength of mortars cured under standard condition and autoclaved condition 
the formation of rich silica calcium silicate hydrate (tobermorite or xonotlite) (Luke 2004; Mindess, Young 1981; Taylor 1997).

The autoclave curing reduced the compressive strength of the CTRL mixture by about $15 \%$ compared to the strength achieved by the standard curing. The reduction in the compressive strength after autoclave curing can be explained by the formation of crystalline $\alpha-\mathrm{C}_{2} \mathrm{SH}$ which is associated with high porosity and less uniformity of the final products. This finding is in conformity with the literature (Yang et al. 2000; Mindess, Young 1981). The results also show that, under autoclave curing cement can be substituted by ground DS up to $40 \%$ without significant loss in the compressive strength.

\subsection{Effect of different autoclave curing cycles on the compressive strength}

DS30 mixture was selected to evaluate the optimum autoclaving temperature and duration because it developed the highest compressive strength under autoclave curing. This mixture was cured at $182,200,210$, and $220{ }^{\circ} \mathrm{C}$ for two periods of curing ( 5 and 8 hours).

Figure 4 shows the effect of different autoclave temperatures and period of curing on the compressive of DS30 mixture. It can be seen that increasing the period of curing from 5 to 8 hours, led to improve the compressive strength of the mixture cured at 182 and $200{ }^{\circ} \mathrm{C}$ by 25 and $16 \%$, respectively. However, prolonging the period of autoclaving at 210 and $220{ }^{\circ} \mathrm{C}$ did not show any improvement on the compressive strength. The maximum compressive strength was achieved when the specimens were cured at $200{ }^{\circ} \mathrm{C}$ for 8 hours. In addition, the compressive strength obtained at 8 hours can be obtained at 5 hours if the temperature is increased from $182{ }^{\circ} \mathrm{C}$ to $200{ }^{\circ} \mathrm{C}$ (Fig. 4).

\subsection{Morphological investigation}

Scanning electron microscope analysis of the CTRL standard curing and DS30 autoclave curing mixtures was conducted on the fracture surfaces of paste samples prepared with similar composition of the mortars.

Figure 5(a) shows the microphotographs of the CTRL mixture cured under standard curing for 28 days. The image shows that the hydrated CSH and crystalline calcium hydroxide $(\mathrm{CH})$ product were dominant. The image of DS30 mixture cured under autoclave condition is shown in Figure 5(b). Hydrated CSH in needle-like structure (tobermorite) can be observed at the centre of the image and no hexagonal crystalline of $\mathrm{CH}$ is appeared. $\mathrm{CH}$ might be consumed by the pozzolanic reaction with silica in the DS.

\subsection{X-ray diffraction (XRD) analysis}

Figure 6 presents the XRD pattern of the DS30 cured under standard condition. Strong peak of quartz at $26.64^{\circ}$

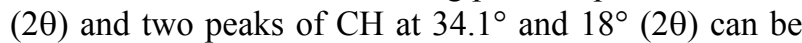
observed. This result reveals that no pozzolanic reaction between $\mathrm{CH}$ and quartz silica took place under stand-

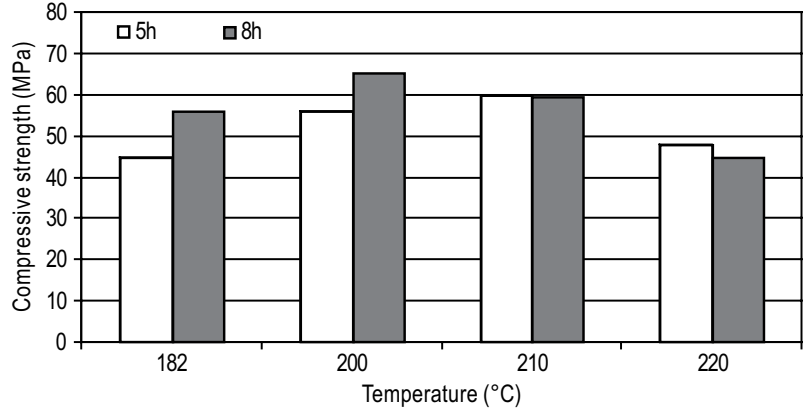

Fig. 4. Effect of different autoclave temperatures and period of curing on the strength of DS30 mixture
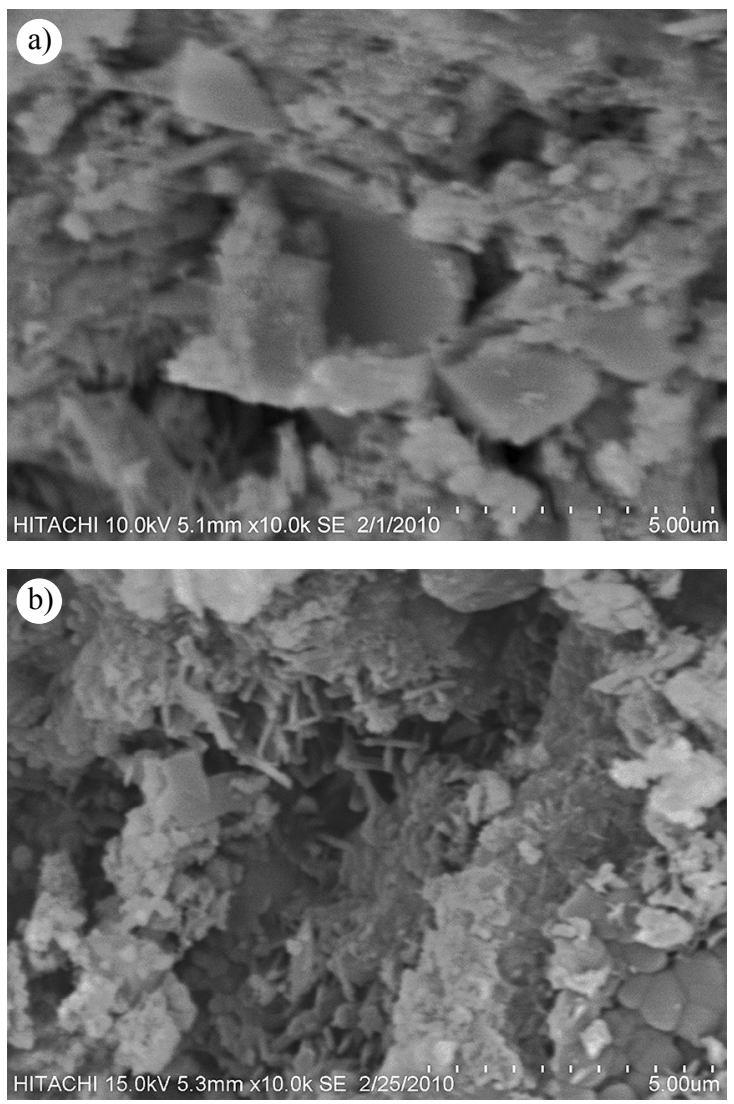

Fig. 5. SEM images: (a) Control mixture under normal; (b) DS30 mixture under autoclave curing

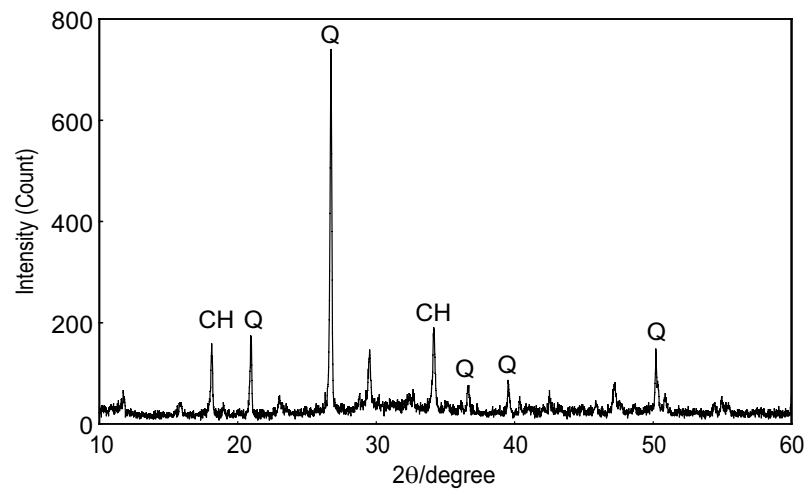

Fig. 6. XRD analysis of DS30 mixture cured under standard condition 


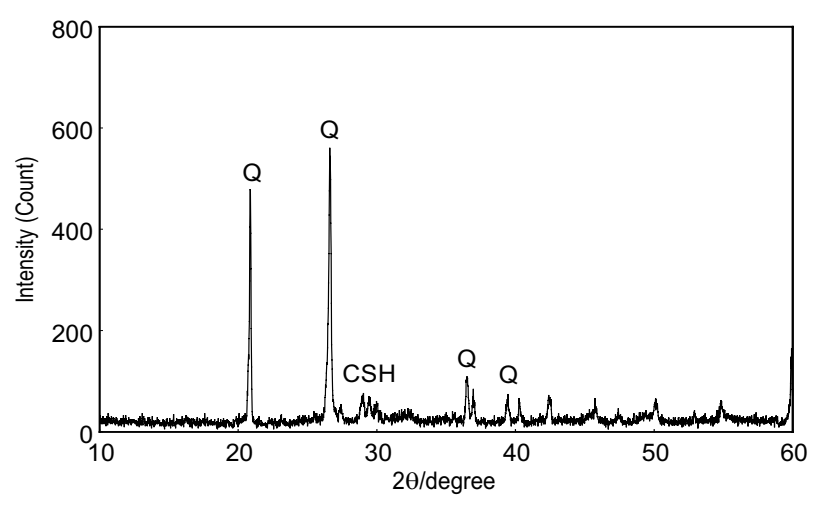

Fig. 7. XRD analysis of DS30 mixture cured under autoclave condition

ard curing and DS acted as a filler material. Ashraf et al. (2009) found similar peaks of $\mathrm{CH}$ at similar positions in the cement paste mixture cured under standard curing.

Figure 7 shows the XRD pattern of the same mixture but cured under autoclave condition. The high peak for the quartz $\left(\mathrm{SiO}_{2}\right)$ decreases but still present in the final products. However, the peaks for $\mathrm{CH}$ are no longer evident. The absence of $\mathrm{CH}$ peaks can be attributed to the pozzolanic reaction between the $\mathrm{CH}$ and ground silica in the DS.

This reaction produces additional cementitious products (i.e. tobormorite) resulting in an enhancement in the compressive strength.

\section{Conclusion}

The effect of ground DS as a partial cement replacement on the compressive strength of mortar cured under standard curing and autoclave curing conditions was investigated. The following conclusion could be drawn:

a) For the standard curing, the compressive strength decreased with an increase in the level of cement replacement by ground DS. However, under autoclaved curing, the DS-cement mixtures enhance the compressive strength. The maximum compressive strength was achieved at $30 \%$ level of replacement;

b) The replacement of cement by ground DS did not modify the normal consistency and the setting time;

c) The highest compressive strength can be achieved by extending the period of autoclave curing or increasing the temperature. But the autoclave temperature should not be higher than $210^{\circ} \mathrm{C}$;

d) SEM study showed that crystalline $\mathrm{CH}$ appeared with standard curing, whereas, tobermorite in needle-like structure can be observed under autoclave curing;

e) After autoclaving, XRD results show that the quartz silica in DS can react with $\mathrm{CH}$ to form additional calcium silicate hydrate. The peak intensity for $\mathrm{CH}$ was absent but residual peaks from quartz silica were still apparent;

f) With autoclave curing, up to $40 \%$ of cement can be substituted by the ground dune sand. This not only enhances the compressive strength but also has a significant impact on the environment.

\section{Acknowledgement}

This study is a part of a joint research project between King Saud University, Saudi Arabia and Universiti Putra Malaysia titled "Development of local sand as a cementitious material for high-performance concrete". The funding of this work by King Saud University is gratefully acknowledged.

\section{References}

Al-Harthy, A. S.; Abdel Halim, M. A.; Taha, R.; Al-Jabri, K. S. 2007. The properties of concrete made with fine dune sand, Construction and Building Materials 21(8): 1803-1808. http://dx.doi.org/10.1016/j.conbuildmat.2006.05.053

Al-Sanad, H. A.; Ismael, N. F.; Nayfeh, A. J. 1993. Geotechnical properties of dune sands in Kuwait, Engineering Geology 34(1-2): 45-52.

http://dx.doi.org/10.1016/0013-7952(93)90042-B

Ashraf, M.; Naeem Khan, A.; Ali, Q.; Mirza, J.; Goyal, A.; Anwar, A. M. 2009. Physico-chemical, morphological and thermal analysis for the combined pozzolanic activities of minerals additives, Construction and Building Materials 23(6): 2207-2213.

http://dx.doi.org/10.1016/j.conbuildmat.2008.12.008

Cassagnabère, F.; Escadeillas, G.; Mouret, M. 2009. Study of the reactivity of cement/metakaolin binders at early age for specific use in steam cured precast concrete, Construction and Building Materials 23(2): 775-784.

http://dx.doi.org/10.1016/j.conbuildmat.2008.02.022

Chandrasekhar, S.; Satyanarayana, K. G.; Pramada, P. N.; Raghavan, P.; Gupta, T. N. 2003. Review processing, properties and applications of reactive silica from rice husk - an overview, Journal of Materials Science 38(15): 31593168. http://dx.doi.org/10.1023/A:1025157114800

Cisse, I. K.; Laquerbe, M. 2000. Mechanical characterisation of filler sandcretes with rice husk ash additions: study applied to Senegal, Cement and Concrete Research 30(1): 13-18. http://dx.doi.org/10.1016/S0008-8846(99)00182-9

Erdem, T. K.; Kırca, Ö. 2008. Use of binary and ternary blends in high strength concrete, Construction and Building $\mathrm{Ma}$ terials 22(7): 1477-1483. http://dx.doi.org/10.1016/j.conbuildmat.2007.03.026

Garcés, P.; Pérez Carrión, M.; García-Alcocel, E.; Payá, J.; Monzó, J.; Borrachero, M. V. 2008. Mechanical and physical properties of cement blended with sewage sludge ash, Waste Management 28(12): 2495-2502. http://dx.doi.org/10.1016/j.wasman.2008.02.019

Ghrici, M.; Kenai, S.; Meziane, E. 2006. Mechanical and durability properties of cement mortar with Algerian natural pozzolana, Journal of Materials Science 41(21): 69656972. http://dx.doi.org/10.1007/s10853-006-0227-0

Guettala, S.; Mezghiche, B. 2011. Compressive strength and hydration with age of cement pastes containing dune sand powder, Construction and Building Materials 25(3): 1263-1269. http://dx.doi.org/10.1016/j.conbuildmat.2010.09.026

Hassan, K. E.; Cabrera, J. G.; Maliehe, R. S. 2000. The effect of mineral admixtures on the properties of high-performance concrete, Cement and Concrete Composites 22(4): 267271. http://dx.doi.org/10.1016/S0958-9465(00)00031-7

Hewlett, P. C. 2003. Lea's chemistry of cement and concrete. Oxford: Elsevier Ltd. 1092 p.

Jaafar, M.; Thanoon, W.; Kadir, M.; Trikha, D. 2002. Strength and durability characteristics of high strength autoclaved stone dust concrete, Indian Concrete Journal 76: 771-775.

Jupe, A. C.; Wilkinson, A. P.; Luke, K.; Funkhouser, G. P. 2008. Class $\mathrm{H}$ cement hydration at $180^{\circ} \mathrm{C}$ and high pressure in 
the presence of added silica, Cement and Concrete Research 38(5): 660-666.

http://dx.doi.org/10.1016/j.cemconres.2007.12.004

Khatri, R. P.; Sirivivatnanon, V.; Gross, W. 1995. Effect of different supplementary cementitious materials on mechanical properties of high performance concrete, Cement and Concrete Research 25(1): 209-220. http://dx.doi.org/10.1016/0008-8846(94)00128-L

Laquerbe, M.; Cisse, I.; Ahouansou, G. 1995. Pour une utilisation rationnelle des graveleux latéritiques et des sables de dunes comme granulats à béton: application au cas du Sénégal, Materials and Structures 28(10): 604-610. http://dx.doi.org/10.1007/BF02473193

Luke, K. 2004. Phase studies of pozzolanic stabilized calcium silicate hydrates at $180{ }^{\circ} \mathrm{C}$, Cement and Concrete Research 34(9): 1725-1732. http://dx.doi.org/10.1016/j.cemconres.2004.05.021

Malhotra, V. M. 1993. Fly ash, slag, silica fume, and rice-husk ash in concrete: a review, Concrete International ACI 15(4): 23-28.

Malhotra, V. M. 2000. Role of supplementary cementing materials in reducing greenhouse gas emissions, in Gjorv O. E.; Sakai, K. (Eds.). Concrete Technology for a Sustainable Development in the 21st Century. London: E \& FN Spon, 226-235.

Malhotra, V. M.; Zhang, M. H.; Read, P. H.; Ryell, J. 2000. Long-term mechanical properties and durability characteristics of high-strength/high-performance concrete incorporating supplementary cementing materials under outdoor exposure conditions, ACI Materials Journal 97(5): 518-525.

Mehta, P. K. 2004. High-performance, high-volume fly ash concrete for sustainable development, in Proc. of the International Workshop on Sustainable Development and
Concrete Technology, 2004, University of California, Berkeley, USA, 3-14.

Mindess, S.; Young, J. F. 1981. Concrete. New York: PrenticeHall Englewood Cliffs. 644 p.

Oyefesobi, S. O.; Roy, D. M. 1976. Hydrothermal studies of type V cement-quartz mixes, Cement and Concrete Research 6(6): 803-810.

http://dx.doi.org/10.1016/0008-8846(76)90010-7

Sabir, B. B.; Wild, S.; Bai, J. 2001. Metakaolin and calcined clays as pozzolans for concrete: a review, Cement and Concrete Composites 23(6): 441-454. http://dx.doi.org/10.1016/S0958-9465(00)00092-5

Taylor, H. F. W. 1997. Cement chemistry. London: Thomas Telford Publishing. 459 p. http://dx.doi.org/10.1680/cc.25929

Thomas, M. D. A.; Shehata, M. H.; Shashiprakash, S. G.; Hopkins, D. S.; Cail, K. 1999. Use of ternary cementitious systems containing silica fume and fly ash in concrete, Cement and Concrete Research 29(8): 1207-1214. http://dx.doi.org/10.1016/S0008-8846(99)00096-4

Worrell, E.; Price, L.; Martin, N.; Hendriks, C.; Meida, L. O. 2001. Carbon dioxide emissions from the Global Cement Industry 1, Annual Review of Energy and the Environment 26(1): 303-329.

http://dx.doi.org/10.1146/annurev.energy.26.1.303

Yang, Q.; Zhang, S.; Huang, S.; He, Y. 2000. Effect of ground quartz sand on properties of high-strength concrete in the steam-autoclaved curing, Cement and Concrete Research 30(12): 1993-1998.

http://dx.doi.org/10.1016/S0008-8846(00)00395-1

Yazıcı, H.; Yiğiter, H.; Karabulut, A. Ş.; Baradan, B. 2008. Utilization of fly ash and ground granulated blast furnace slag as an alternative silica source in reactive powder concrete, Fuel 87(12): 2401-2407.

http://dx.doi.org/10.1016/j.fuel.2008.03.005

Abdulrahman ALHOZAIMY. Professor, Civil Engineering Department, King Saud University, Riyadh, Saudi Arabia. He received his BS from King Saud University and MS and PhD from Michigan State University, USA. His research interests concentrate on concrete technology with emphasis on hot weather concreting and concrete durability.

Omer Abdalla ALAWAD. He obtained his Master's degree at Universiti Putra Malaysia and is currently continuing PhD at the same university. His research interest is structural and concrete materials.

Mohd Saleh JAAFAR. Professor, obtained his PhD from the University of Sheffield. Currently, Professor and Deputy Vice Chancellor (Research \& Innovation), UPM, Malaysia. His research interests include concrete and prestressed concrete structures, high performance concrete and structural conditions assessment.

Abdulaziz AL-NEGHEIMISH. Associate Professor, Civil Engineering Department, King Saud University, Riyadh, Saudi Arabia. He received his BS and MS from the University of Michigan, Ann Arbor and PhD from the University of Texas at Austin, USA. His research interests include housing construction, quality scheme for ready-mixed concrete and hot weather concreting.

Jamaloddin NOORZAEI. Professor, completed his PhD study at the University of Roorkee, India. Currently he is an Associate Professor and the Head of the Structural Engineering Research group at the Universiti Putra Malaysia (UPM). His research interests include computational techniques in civil engineering applications especially those related to structural engineering, soil-structure interaction and earthquake engineering. 